\title{
ANTLAŞMALAR VE AVRUPA BİRLİĞİ ADALET DİVANI KARARLARI ÇERÇEVESINDE AVRUPA BİRLIĞİ VATANDAŞLIĞI
}

\section{Kerem BATIR*}

\section{$\ddot{\boldsymbol{O}} \boldsymbol{z}$}

Avrupa Birliği vatandaşlı̆̆ kavramı Maastricht Antlaşmass ile getirilmiş bir kavram olup Avrupa Topluluğu'nda Avrupa Topluluğu üyesi ülkelerin vatandaşlarının sahip olduklarl dört temel özgürlüğe ilaveten Avrupa Topluluğu'nun siyasi ve ekonomik bir birliğe dönüşmesi esnasinda vatandaşların da bu birlik içindeki statülerini güçlendirmek üzere ortaya çıkmıştır. Maastricht Antlaşmasından sonraki dönemde Amsterdam, Nice ve Lizbon Antlaşmaları ile kavram geliştirilmiş ve bugünkü halini almıştır. Bu çalışmada Avrupa Topluluklarının kuruluşundan bu yana üye devlet vatandaşlarının sahip olduğu haklar değerlendirilecek ve Avrupa Birliği Adalet Divanı'nın Avrupa Birliği vatandaşlığına ilişkin önemli kararları ışı̆̆ında Avrupa Vatandaşlı̆̆ kavramının kapsamı, vatandaşlık kavramı ile benzerlikleri ve farklilıklarl ile gelişim süreci üzerinde durulacaktır. Bu bağlamda son dönemde Avrupa Birliği-Türkiye ortaklık ilişkisi çerçevesinde ortaya atılan Ortaklık Vatandaşlı̆̆ kavramına da dĕ̆inilecektir.

Anahtar Kelimeler: Avrupa Birliği, Vatandaşlık, AB Vatandaşlı̆̆,$A B$ Adalet Divanı Kararları, Ortaklık Vatandaşlı̆̆ı

\section{EUROPEAN UNION CITIZENSHIP WITHIN THE FRAMEWORK OF TREATIES AND COURT OF JUSTICE OF THE EUROPEAN UNION'S DECISIONS}

\section{Abstract}

The term European Union citizenship came into being with the Maastricht Treaty where European Community turned to an economic and political union and in order to empower the status of citizens within the union and additional to the four fundamental freedoms that citizens of the European Community member states enjoyed. The term has been in an evolution process after the

\footnotetext{
* Doç.Dr., İzmir Katip Çelebi Üniversitesi, İktisadi ve İdari Bilimler Fakültesi, Uluslararas1 İlişkiler Bölümü, e-posta: kerem.batir@ikc.edu.tr
} 
Maastricht Treaty by Amsterdam, Nice and Lisbon Treaties. This study will evaluate the rights of the citizens of member states from the establishment of the European Communities together with the concept of the European citizenship in the light of the important decisions of the Court of Justice of the European Union, similarities and differences between the European Union citizenship and ordinary citizenship and evolution process. Within this context Association Citizenship, a term within the framework of European Union-Turkey association regime, shall also be referred.

Keywords: European Union, Citizenship, EU Citizenship, Court of Justice of the European Union, Association Citizenship

\section{Giriş}

Vatandaşlık birey ile devlet arasında kurulan, kişinin etnik kökenini ifade etmeyen hukuki bir bağdır ${ }^{1}$. Literatürde vatandaşlık kavramı iki temel elementin bir araya gelmesi olarak ele alınmıştır. Bunlardan birincisi bir statü olarak vatandaşlıktır ve devlet ile birey arasında mevcut hukuki bağdır. Diğeri ise bir hak olarak vatandaşliktır ve bireyin bir topluma mensubiyeti nedeniyle haklara sahip olması demektir (Bosniak, 2002: 1288). Vatandaşların sahip oldukları haklardan yararlanmanın ön koşulu vatandaş olmaktır. Dolayısıyla önce statü olarak vatandaşlik statüsünde olunacak sonra vatandaşların sahip oldukları haklardan yararlanılmaya başlanacaktır.

Vatandaşlık hukukun değişik alanlarında önemli rollere sahip olan bir kavramdır. Vatandaşlık kavramı ulusal hukuklarda olduğu kadar uluslararası hukukta da düzenlenmiş, kurallara bağlanmıştır. Bu kurallar devletten devlete değişiklikler göstermektedir. Devletle birey arasındaki bağ temelde aynı olmakla birlikte değişik ülkelerde değişik biçimlerde anlaşılabilmektedir. $\mathrm{Bu}$ nedenle her devlet kendi ulusal hukuk sisteminde diğer devletlerden bağımsız olarak vatandaşlığa ilişkin kuralları düzenler. Uluslararası Daimi Adalet Divanı'nın Tunus ve Fas Vatandaşlık Kararnameleri Meselesi kararında "uluslararası hukukun hali hazırdaki durumunda vatandaşlık meseleleri, prensip itibarıla, mahfuz sahaya (reserve domain) dahildir" demek suretiyle devletlerin vatandaşlığa ait kuralları kendi iç hukuklarında düzenleyebileceklerini hükme bağlamıştır (Tunus ve Fas Vatandaşlık Kararnameleri Meselesi Tavsiye Görüşü, 1923).

${ }^{1}$ Bu tanım Avrupa Vatandaşlık Sözleşmesi’nin 2. Maddesinde yapılmış olup genel olarak kabul gören bir tanımdır. 
Vatandaşlık geçmişten bugüne devlet egemenliği ile çok yakın ilişkili bir kavram olarak kabul edilmiştir. Küreselleşen dünyada, uluslararası bağlantıların önem kazandığı bir dönemde egemenlik anlayışı da değişim göstermektedir. $\mathrm{Bu}$ anlayış değişikliğinin bir sonucu vatandaşlığa ilişkin anlayış da değişmekte olup artık devletlerin çok vatandaşlığa sahip kişilere karşı yaklaşımları da değişim göstermeye başlamıştır (Hailbronner, 2006: 36).

Avrupa Birliği (AB) vatandaşlığı da vatandaşlığın değişen algısına katkıda bulunmaktadır. AB vatandaşlığ farklıdır. AB ilk ve şu ana kadar tek ulusüstü örgüt olarak modern vatandaşlık anlayışında gerçek bir devrime imza atmıştır. Lizbon Antlaşması'ndan sonra değiştirilen $\mathrm{AB}$ Antlaşması'nın başlangıç kısmında "ülkelerinin vatandaşları için ortak bir vatandaşlık tesis etmeye kararlı olarak" ibaresi yer almaktadır. Bu amaç doğrultusunda Avrupa Birliği'nin İşleyişi Hakkındaki Antlaşma’nın ikinci kısmında sayılan hakların ve bu hakların kapsamını genişleten Adalet Divanının proaktif kararlarının da desteği ile $\mathrm{AB}$ vatandaşlığı kavramı bugünkü kapsamına kavuşmuştur.

$\mathrm{AB}$ vatandaşı olabilmek için $\mathrm{AB}$ üyesi devletlerden birinin vatandaşı olmak zorunludur. $\mathrm{Bu}$ açıdan $\mathrm{AB}$ vatandaşlı̆̆ 1 ikincil nitelikte bir vatandaşlık olup, bireye $\mathrm{AB}$ içerisinde kendi vatandaşı olduğu devletten bağımsız haklar bahşeden bir statü olarak karşımıza çıkmaktadır.

$\mathrm{AB}$ vatandaşlığı kavramı da tıpkı AB hukukunun diğer alanlarında olduğu gibi süreç içinde kapsamı Adalet Divanı kararları ve Antlaşmalarla genişleyen, Avrupa Toplulukları'nın kuruluşundan bu yana üye devlet vatandaşlarına tanınan bir takım hakların konsolide edilerek vatandaşlık kavramı altında bir araya getirilmesi ile oluşturulmuş sui generis bir vatandaşl1k türüdür.

\section{Avrupa Vatandaşlığının Kısa Tarihçesi}

Avrupa Ekonomik Topluluğu'nu kuran Roma Antlaşması, üye devletlerin vatandaşlarını Topluluk vatandaşı olarak görmekten ziyade onların sosyal ve ekonomik statüleri üzerinde durmakta ve onlara "işçiler", "serbest meslek sahipleri”, "hizmet sağlayanlar”, "işsizler”, “emekliler” yahut "öğrenciler” gibi sifatlarla atıfta bulunmaktayd.

Avrupa entegrasyonu içinde "vatandaşlık" teriminin ilk kullanımı 1970'li yıllara dayanmaktadır. Kochenov, ulusüstü vatandaşlık fikrinin 1973 Kopenhag Zirvesi ile başladığı yolunda literatürde çok sayıda çalışma olduğunu ileri sürmektedir (Kochenov, 2009:172). 
9-10 Aralık 1974 yılında yapılan Paris devlet ve hükümet başkanları zirvesinde tüm üye devletlerin vatandaşları için standart pasaport uygulaması ve müteakiben bir "pasaport birliği" planı topluluk vatandaşlarına özel birtakım hakların verilmesi anlamında ilk çalışma olmuştur (Condinanzi, 2008: 1). Bu zirve, Komisyondan üye devletlerin vatandaşlara Topluluk üyesi olmaları nedeniyle bahşedilen özel hakların incelenmesini talep etti. İkamet edilen yerlerde yerel seçimlerde aday olma ve oy kullanma hakk1 o tarihlere dayanmaktadır. 1975 yılında sunulan Tindemans Raporu bir dizi vatandaşlık hakkının Topluluk üyesi devletlerin vatandaşlarına tanınmasını tavsiye ediyordu. $\mathrm{Bu}$ haklar arasında "kamu hizmetlerine eşit erişim, sınır kontrollerinin kaldırılması, okul ve ögrenci değişim programlarının desteklenmesi, diplomaların karşılıklı tanınması ve geliştirilmiş tüketici koruması" sayılabilir (Tindermans, 1976).

1984 yılında Altiero Spinelli tarafından hazırlanan ve Avrupa Parlamentosu tarafindan kabul edilen "Avrupa Birliği'ni Kuran Taslak Antlaşma” metni "Birlik Vatandaşlığı" teriminin ilk kez kullanıldığı metin olarak karşımıza çıkmaktadır. Taslak metnin 3. maddesi "Birlik Vatandaşlığı" başlığını taşımaktadır ve üye devletlerin vatandaşlarının ipso facto birlik vatandaşı olduklarını, birlik vatandaşlığının üye devlet vatandaşlığına bağlı olduğunu ve birlik vatandaşlığının bağımsız olarak kazanılıp kaybedilemeyeceğini hükme bağlamıştır (Bulletin of the European Communities, 1984). Bu taslak metin yürürlüğe girememiştir. 1 Temmuz 1987 tarihinde yürürlüğe giren Avrupa Tek Senedi'nde Avrupa Vatandaşlığı kavramı antlaşma metninde yer almamıştır.

1987 yılında AT Konseyinin öğrenci değişimine ilişkin "Erasmus" Kararı (87/327 EEC, 1987) "Vatandaşlar için Avrupa" referansıyla yapılan ilk hukuki düzenleme olarak kabul edilmektedir. 1988 yılında Komisyon yerel seçimlerde oy kullanma hakkına ilişkin hazırladığı taslağı sunmuştur. 1990 yılına gelindiğinde AT Konseyi oturum hakkına ilişkin 90/364/EEC sayılı Direktifi ${ }^{3}$, hâlihazırda çalışmayan kişilerin kendi ülkeleri dışında ikamet haklarına ilişkin olarak 90/365/EEC sayılı Direktifi ${ }^{4}$ ve öğrencilerin oturum haklarına ilişkin 90/366/EEC sayılı Direktifi ${ }^{5}$ kabul etmiştir (Kadelbach, 2003:6).

\footnotetext{
2 87/327 EEC sayılı Üniversite Öğrencilerinin Hareketliliği hakkında Avrupa Topluluğu Eylem Planı (ERASMUS)

3 90/364/EEC sayılı İkamet Hakkına İlişkin Yönerge

${ }^{4}$ 90/365/EEC sayılı Mesleki Faaliyetleri Sona Eren İşçilerin ya da Serbest Meslek

Sahiplerinin İkamet Haklarına İlişkin Yönerge

5 90/366 EEC sayılı Öğrencilerin İkamet Haklarına İlişkin Yönerge
} 
Maastricht Antlaşması önceki dönemde AB vatandaşlığı kavramının oluşturulmasında serbest dolaşımın ve siyasi hakların en önemli konular olarak ele alındığını söylemek yanlış bir tespit olmayacaktır.

\section{Maastricht Antlaşması ve AB Vatandaşlığı}

Maastricht Antlaşmasının kabul edildiği hükümetler arası konferans esnasında en çok konuşulan konu AT karar alma süreçlerindeki demokratik eksiklik (democratic deficit) meselesi olmuş ve konferans esnasında demokratik meşruiyeti arttırmaya yönelik öneriler getirilmiştir (Closa, 1992: 1153-1157).

1993 yılında yürürlüğe giren resmi adıyla Avrupa Birliğini Kuran Antlaşma'nın (Maastricht Antlaşması) İkinci Bölümü "Birlik Vatandaşlığı" başlığını taşımaktaydı. 8. madde birlik vatandaşlığının tesis edildiğini ve bir üye devletin uyrukluğunda olan herkesin birlik vatandaşı olduğunu bildiriyordu. Birlik vatandaşlarının antlaşmada öngörülen haklardan yararlanabilecekleri ve yükümlülüklere tabi oldukları da aynı maddede ifade ediliyordu.

Maastricht Antlaşması'nda Birlik vatandaşlarının sahip oldukları haklar şöyledir:

a. Serbestçe dolaşmak ve ikamet etmek,

b. İkamet ettiği üye devletin vatandaşları ile aynı koşullarda mahalli seçimlerde oy kullanmak ve seçilmek,

c. İkamet ettikleri üye devlette bu devletin kendi vatandaşları ile aynı koşullarda Avrupa Parlamentosu seçimlerinde oy kullanmak ve aday olmak,

d. Vatandaşı olduğu üye devletin temsil olunmadı̆̆ı üçüncü ülkelerin topraklarında, bütün üye devletlerin, söz konusu üye devlet uyrukları ile aynı koşullarda diplomatik ve konsolosluk yetkililerinin korumasından yararlanmak,

e. Antlaşmanın 138/d maddesi hükmü uyarınca Avrupa Parlamentosu nezdinde şikayet hakk1

Maastricht Antlaşması ile Birlik vatandaşlı̆̆ı kavramının getirilmesinden bazı üye devletler endişe etmişlerdir. Bu kavramın kendi vatandaşlık yasaları çerçevesinde vatandaşlı̆̆ın kazanılması ya da kaybedilmesine ilişkin koşulları belirleme yetkilerine halel getirebileceğinden kuşkulanarak bu durumun netleştirilmesi için girişimlerde bulunmuşlardır. 11-12 Aralık 1992 tarihinde toplanan Devlet ve Hükümet Başkanları Zirvesinde Danimarka tarafından ileri sürülen bazı problemlere istinaden aşağıda belirtilen karar alınmıştır: 
Avrupa Topluluğunu kuran Antlaşmanın İkinci Bölümünde yer alan Birlik vatandaşlığına ilişkin hükümler Üye Devletlerin vatandaşlarına ilgili bölümde belirtilen ilave haklar ve koruma sağlamaktadır. Bu hükümler hiçbir şekilde ulusal vatandaşlı̆̆ın yerini alamazlar. Bir bireyin bir Üye Devletin vatandaşlığına sahip olup olmaması meselesi münhasıran ilgili Üye Devletin ulusal yasaları çerçevesinde karara bağlanacaktır (Edinburgh Zirvesi,1992).

Danimarka Maastricht antlaşmasının kabulü sırasında yayımladığı bir deklarasyonla Birlik vatandaşlığının siyasi ve hukuki olarak Danimarka Krallığ Anayasası'nda belirtilen vatandaşlık konseptinden tamamen farklı bir konsept olduğunu beyan etmiştir. Danimarka Faroe Adalarında ikamet eden vatandaşlarını AB vatandaşlı̆̆ı statüsünden hariç tutmuş, yine 1982 referandumu sonrası Grönland'ın Avrupa Topluluğundan çıkmasından sonra Grönland'da ikamet eden Danimarka vatandaşları da AB vatandaşlığından hariç tutulmuşlardır. Hollanda ise denizaşırı topraklarında ikamet eden vatandaşlarına Hollanda'da ya da başka bir Üye Devlette bulundukları esnada AB vatandaşlığından yararlanma hakkını tanımıştır (Kruma, 2014: 130).

$\mathrm{Bu}$ dönemde yazarlar $\mathrm{AB}$ vatandaşlı̆̆ının Üye Devlet vatandaşlıklarını ilga etmediğini aksine Üye Devlet vatandaşları için ikinci grup ilave haklar yarattığını, bu ilave hakların en belirgin özelliğinin birinci grup haklardan sadece bir Üye Devlet içinde yararlanmak mümkün iken ikinci grup yeni haklardan her üye Devlette yararlanmanın mümkün olduğunu kabul etmişlerdir (Closa, 1995: 493).

\section{Amsterdam Antlaşması}

1997 yılında imzalanan Bütünleştirilmiş Haliyle Avrupa Birliği Kurucu Antlaşmalar ya da Amsterdam Antlaşması, Avrupa vatandaşlarının haklarını güçlendiren bir metindir (Amsterdam Antlaşması, 2000).

Amsterdam Antlaşması, AB kurumlarına dört temel özgürlükten biri olan serbest dolaşım hakkı için gerekli olan göçmenlik, özel hukuk, medeni usul hukuku gibi alanlarda ikincil mevzuat yaratma konusunda yetki vermiştir. Antlaşma ile daha önce AB'nin müktesebatı içinde yer almayan Schengen Antlaşmaları da AB mevzuatına dâhil edilmiştir.

Amsterdam Antlaşması, Maastricht Antlaşması'nın madde numaralarını da değiştirmiş, $\mathrm{AB}$ vatandaşlı̆g 1 konusunu ikinci bölümde 17-22 maddeleri ile düzenlemiştir. Maastricht Antlaşması'nın kabulü esnasında üye devletlerden gelen itirazlar dikkate alınarak 17. maddede "Birlik vatandaşlığı ulusal vatandaşlığın yerini almayıp onu tamamlar" şeklinde bir hüküm eklenmiştir. Dolayısıyla birlik vatandaşlığı statüsünden faydalanmak için öncelikle üye 
devlet vatandaşı olmak zorunludur. Üye devlet vatandaşları için birlik vatandaşlığı otomatik olarak kazanılan bir statüdür.

\section{Nice Antlaşması}

Nice Antlaşması, Avrupa Birliği Antlaşması'nı ve Avrupa Topluluklarını Kuran Antlaşmaları tadil etmiş ve yeni düzenlemeler getirmiştir. 26 Şubat 2001'de Nice'de imzalanmış ve 1 Şubat 2003'te yürürlüğe girmiştir. Nice Antlaşması o dönemde Orta ve Doğu Avrupa devletlerini içeren kapsamlı bir genişleme hamlesi için gereken kurumsal reformların hayata geçirildiği bir antlaşmadır. Antlaşmanın yürürlüğe girmesinden bir yıl sonra on devlet AB üyesi olmuş, dört yıl sonra Bulgaristan ve Romanya'nın da katılımı ile sayı on ikiye çıkmıştır (Nice Antlaşması, 2003).

Nice Antlaşması ile vatandaşlık alanında getirilen yenilik Avrupa Topluluğunu Kuran Antlaşmanın 18. maddesinde yapılan değişikliktir. Bu madde Birlik vatandaşlarının başka üye devletlerde serbest dolaşım ve ikamet hakkını düzenleyen maddedir. Maastricht Antlaşması'nda Topluluk bu hakların kullanımını kolaylaştırmaya yönelik hükümler kabul edebileceğini, ancak karar alma usulünün "danışma usulü" olacağı kabul edilmiştir. AB Bakanlar Konseyi Avrupa Parlamentosu'na danıştıktan sonra oybirliği ile karar verebilecektir.

Amsterdam Antlaşması'nda danışma usulü yerine “ortak karar usulü” getirilmiş ancak AB Bakanlar Konseyi'nin bu usul çerçevesinde oybirliği ile hareket edeceği hükme bağlamıştır. Nice Antlaşması ise bu alanda karar alabilmek için AB Bakanlar Konseyindeki oybirliği şartını kaldırmış ancak maddeye üçüncü paragraf ekleyerek "pasaport, kimlik kartı ve oturma iznine ilişkin hükümler ya da sosyal güvence veya korumaya ilişkin herhangi bir belge ya da hükümler için ikinci paragrafın geçerli olmayacağı” hükme bağlanmıştır.

\section{Lizbon Antlaşması}

29 Mayıs 2005 tarihinde Fransa'da ve 1 Haziran 2005 tarihinde Hollanda'da gerçekleştirilen halk oylamaları sonucunda reddedilen AB Anayasası'nın akim kalmasının yarattığ 1 boşluğu doldurmak üzere, temel yaklaşımı muhafaza eden ancak küçük değişikliklerle mevcut antlaşmalarda reform yapan Lizbon Antlaşması, Avrupa Birliği Antlaşması ile Avrupa Topluluğunu Kuran Antlaşma'ya değişiklikler getirmiş olup getirilen değişiklikler arasında AB vatandaşlığına ilişkin maddeler de vardır ${ }^{6}$ (Lizbon Antlaşması, 2011).

${ }^{6}$ Lizbon Antlaşması ile birlikte Avrupa Topluluğunu Kuran Antlaşmanın adı Avrupa Birliği'nin İşleyişine İlişskin Antlaşma olarak değiştirilmiştir. 
Lizbon Antlaşması ile birlikte Avrupa Birliği Antlaşması'nın başlangıç kısmında birlik vatandaşlığına atıfta bulunulmuş ve "ülkelerin vatandaşları için ortak bir vatandaşlık tesis etmeye kararlı olarak... bir Avrupa Birliği kurmaya karar vermiş" demek suretiyle Avrupa Birliği'nin kuruluş amaçları arasında Birlik vatandaşlığııı da göstermiştir.

Avrupa Birliği Antlaşması'nın “Demokratik İlkelere İlişkin Hükümler” başlığını taşıyan ikinci başlığı altında yer alan 9. maddesi Birliğin vatandaşları arasında eşitlik ilkesinin gözetileceği ifade edilmiş ayrıca aynı maddede "Bir Üye Devletin uyruğu olan her kişi Birlik vatandaşı olarak tanımlanmıştır. Birlik vatandaşlığı, ulusal vatandaşlığa ilave nitelikte olup ulusal vatandaşlığın yerini almaz" demek suretiyle daha önce Amsterdam Antlaşması'nda yapıldı̆̆ üye devletlerin kaygıları giderilmeye çalışılmıştır. Aynı başlık altında yer alan 10. maddede ise vatandaşların Birlik düzeyinde Avrupa Parlamentosunda doğrudan temsil edilecekleri ve her vatandaşın AB'nin demokratik yaşamına katılma hakkına sahip olduğu hususları düzenlenmiştir.

Antlaşmanın 11. maddesi vatandaş inisiyatifini tanımlamakta olup en az bir milyon AB vatandaşının Avrupa Komisyonu'nu yetkileri çerçevesinde öneri sunmaya davet etme girişiminde bulunabileceklerini düzenlemiştir. Birlik vatandaşlarına bu yolla yasalaşma sürecini başlatabilecek bir hak tanınmıştır.

Avrupa Birliğinin İşleyişi Hakkındaki Antlaşmanın ikinci kısmı “Ayrımcılık Yapmama ve Birlik Vatandaşlığı” başlığını taşımaktadır. Birlik vatandaşlarının sahip olduğu haklar 20. maddede sayılmış ve takip eden maddelerde detaylandırılmıştır. Burada sayılan haklar tahdidi değildir, Antlaşmalarda öngörülen diğer hakların yanı sıra Birlik vatandaşlarına tanınmıştır.

Avrupa Birliği’nin İşleyişi Hakkındaki Antlaşma'nın mevcut halinde Birlik vatandaşlarının sahip oldukları haklar şöyle sıralanmıştır:

a) Üye devletlerin topraklarında serbestçe dolaşma ve ikamet etme hakkl:

Antlaşmanın 21. maddesine göre her AB vatandaşı, bu Antlaşmalarda öngörülen sınırlamalar, şartlar ve bunların uygulanması için kabul edilen tedbirler çerçevesinde, üye devletlerin topraklarında serbestçe dolaşma ve ikamet etme hakkına sahiptir. Bu hakların kullanımının kolaylaştırılması için Avrupa Parlamentosu ve Konsey olağan karar alma usulünü kullanarak yasama faaliyeti yapabilecektir. Ancak serbest dolaşım kapsamında sosyal güvenlik ve sosyal korumaya ilişkin kararların alınmasında Üye Devletlerin hassasiyetleri gözetilerek olağan karar alma usulü yerine özel karar alma usulü kullanılacak ve Avrupa Parlamentosuna danışıldıktan sonra Konsey tarafından oybirliği ile yapılan düzenlemeler kabul edilebilecektir. Hailbronner ve Sanchez serbest 
dolaşım hakkını bu şekilde ikincil mevzuat ile yapılacak düzenlemelere bağlı kılmanın "anayasal hak" yaratmaktan önemli bir dönüş olarak tanımlamaktadırlar (Hailbronner ve Sanchez, 2011:502).

b) İkamet ettikleri üye devlette, o devletin vatandaşlarıla aynı şartlarda, Avrupa Parlamentosu seçimlerinde ve yerel seçimlerde seçme ve seçilme hakkl:

Antlaşmanın 22. maddesine göre vatandaşı olmadığ bir üye devlette ikamet eden her $\mathrm{AB}$ vatandaşı, ikamet ettiği üye devlette, o devletin vatandaşları ile aynı koşullarda, yerel seçimlerde seçme ve seçilme hakkına sahiptir. Buna benzer bir biçimde bu kişilerin Avrupa Parlamentosu seçimlerinde de seçme ve seçilme haklarına sahip olmaları söz konusudur. Seçme ve seçilme hakları, Konsey'in özel karar alma usulü uyarınca ve Avrupa Parlamentosu'na danıştıktan sonra oybirliğiyle kabul ettiği düzenlemelere uygun olarak kullanılabilecektir. Yine bu konuda hassas olan üye devletlerin bu kurallarda, kendilerine özgü sorunlar gerekli kıldığında derogasyonlar öngörebilecekleri de kabul edilmektedir.

c) Vatandaşı olduğu üye devletin temsil edilmediği üçüncü bir ülkenin topraklarında, üye devletlerden herhangi birinin diplomatik veya konsolosluk makamlarınca, o üye devletin uyruklarıyla aynı şartlarda korunma hakkı:

Antlaşmanın 23. maddesine göre her $\mathrm{AB}$ vatandaşı, vatandaşı olduğu üye devletin diplomatik temsilciliği bulunmayan bir üçüncü ülke sınırları içinde diğer üye devletlerden herhangi birinin diplomatik veya konsolosluk makamlarınca, o üye devletin vatandaşlarına sağlanan koşullarla korunma hakkına sahip oldukları hükme bağlanmıştır. Üye devletler, diğer üye devlet vatandaşlarına böyle bir korumayı sağlamak için kendi iç hukuklarında gerekli değişiklikleri yapmakla mükelleftirler, bu uğurda gerekli uluslararası müzakereleri de başlatacaklardır. Yine bu korumayı kolaylaştırmak için Konsey, özel yasama usulü uyarınca hareket ederek ve Avrupa Parlamentosu'na danıştıktan sonra, gerekli koordinasyon ve işbirliği tedbirlerini öngören yönergeler kabul edebilecektir.

d) Avrupa Parlamentosu'na dilekçe verme, Avrupa Ombudsmanı'na başvurma ve Birlik kurumlarına ve danışma organlarına Antlaşmaların dillerinden birinde başvurma ve aynı dilde cevap alma hakkı:

Antlaşmanın 24. maddesi uyarınca her AB vatandaşı Avrupa Parlamentosu'na dilekçe verme hakkına sahiptir. Yine her AB vatandaş1 Ombudsman'a başvurma hakkına da sahiptir. Avrupa Parlamentosu ve Konsey, Avrupa Birliği Antlaşması'nın 11. maddesi hükümleri çerçevesinde, yurttaş 
girişimi için gerekli prosedürleri oluşturmak, girişime katılması gereken yurttaşların en az kaç üye devletten gelmesi gerektiği hususundaki asgari sayısı da dâhil olmak üzere, olağan karar alma usulü uyarınca hareket ederek, tüzükler yoluyla düzenleyecektir.

e) Vatandaşlık temelli ayrımcılık yasă̆l:

18. maddede belirtilen ayrımcılık yasağı Antlaşmanın 20. maddesinde sayılan $\mathrm{AB}$ vatandaşlarının sahip olduğu haklar arasında açıkça sayılmamasına karşın $A B$ vatandaşlığını düzenleyen ikinci kısmın başlığının "Ayrımcılık Yapmama ve Birlik Vatandaşlı̆̆ı" olması farklı üye devletlerin vatandaşı olmak temelli ayrımcılığın yasaklanması ve bu yasağın Adalet Divanı tarafından üye devlet vatandaşlarına benzersiz bir şekilde uygulanması sayesinde $A B$ vatandaşlığı kavramı ile aynı perspektifte değerlendirilmektedir. Başka bir anlatımla $\mathrm{AB}$ içinde ikamet eden üçüncü ülke vatandaşlarına uygulanmayan fakat münhasıran $\mathrm{AB}$ vatandaşları tarafından faydalanılan son derece önemli bir haktır (Kochenov, 2009: 207).

Vatandaşlık temelli ayrımcılık yasağı $\mathrm{AB}$ vatandaşlarının serbest dolaşımı ile çok yakından ilgilidir. Vatandaşlar açısından ayrımcılık yasağı bir diğer Üye Devlete karşı ileri sürülebilecek temel bir haktır (Pennings, 2013: 119).

Antlaşmanın 25. maddesi Komisyon'a her üç yılda bir AB vatandaşlığına ilişkin ikinci kısımda yer alan hükümlerin nasıl uygulandığının tespitine ilişkin olarak Avrupa Parlamentosu'na, Konsey'e ve Ekonomik ve Sosyal Komite'ye rapor verme sorumluluğunu yüklemiştir. Konsey bu raporu esas alarak özel karar alma usulü çerçevesinde Avrupa Parlamentosu'nun onayını aldıktan sonra, $\mathrm{AB}$ vatandaşlığına ilişkin Antlaşmada belirtilen hakları güçlendirmeyi veya ilave haklar getirmeyi amaçlayan düzenlemeleri oybirliğiyle kabul edebilir. Ancak bu düzenlemeler doğrudan uygulanabilir olmayıp, Üye Devletler tarafından kendi iç hukuk düzenlemeleri çerçevesinde onaylandıktan sonra yürürlüğe girecektir.

Görüldüğü gibi $\mathrm{AB}$ vatandaşlarının sahip olacakları haklar sınırlandırılmış değildir, aksine sürekli gözden geçirilip güçlendirilebilir yahut ilave haklar kabul edilebilir. Ancak AB vatandaşlığı konusu hala hassas bir konu olarak kabul edilmekte, bu konuda yetki Parlamento ile paylaşılmamakta, bizzat Konsey tarafından kullanılmakta, hatta Konseyin oybirliği ile kabulü de yetmemekte, üye devletler tarafından anayasalarına uygun olarak onaylanmas1 gerekmektedir.

Antlaşmanın 20. maddesinde sayılan haklar dışında $A B$ vatandaşlarının ayrımcılığa uğramama, temel ekonomik özgürlükleri (işçilerin serbest dolaşımı, 
yerleşme özgürlüğü, hizmet sağlama özgürlüğü gibi) icra etme, kadın ve erkek çalışanlar için eşit işe eşit ücret hakkı ve Antlaşmanın sosyal politikaya ilişkin hükümleri çerçevesinde korunmaya ilişkin haklar gibi hakları da vardır.

Antlaşmanın 20. maddesinde sayılan hakların bir kısmı doğrudan Birlik kurumlarına karşı ileri sürülebilirken diğer bir kısmı ise Üye Devletlerce, AB vatandaşlarının Birlik vatandaşlığı statüsünden doğan haklarının kendi topraklarında garanti edilmesi zorunluluğunu beraberinde getirmektedir.

\section{AB Temel Haklar Şartı}

AB Temel Haklar Şartı, AB tarafından 7 Aralık 2000 tarihinde Nice'de imzaya açılan ve bireylere birtakım temel haklar tanıyan bir belgedir (Avrupa Birliği Temel Haklar Şartı, 2011). Temel Haklar Şartı bakanlar düzeyinde kabul edilmiştir. Daha sonra AB Anayasası hazırlık çalışmaları esnasında bu Şartın $\mathrm{AB}$ Anayasası metnine dâhil edilmesi fikri kabul görmüştür. Ancak bu $\mathrm{AB}$ Anayasası'nın onay sürecinde Fransa ve Hollanda'da halkoylaması sonucu reddedilmesinden dolayı bu girişim akamete uğramıştır. Nihayet Temel Haklar Şartı Lizbon Antlaşması'na dâhil edilmek suretiyle AB hukukunun birincil kaynaklarının bir parçası olmuştur. İngiltere ve Polonya imzaladıkları bir protokolle bu bildirgeye sınırlı bir şekilde katılmışlardır.

Avrupa Birliği mevcut yetkileri çerçevesinde Avrupa İnsan Hakları Sözleşmesi'ne taraf olamamaktadır. Bu nedenle kendisi bu Temel Haklar Şartı'nı oluşturmuştur. Bu şart hem Avrupa İnsan Hakları Sözleşmesi'nin maddelerini kapsar, hem de kendi antlaşmalarında önceden kabul ettiği hükümlerle evrensel çerçevede Birleşmiş Milletler kararlarını da içine alır. $\mathrm{Bu}$ hüküm ve kararlar ekonomik ve politik haklardan, iyi yönetim ve temiz çevre hakkı gibi üçüncü kuşak haklara kadar geniş bir yelpazeye yayılan toplumsal hakları içerir.

Temel Hakları Şartı'nın beşinci bölümü "Vatandaş Hakları” başlığını taşımaktadır. Bölümde yer alan 39. maddede Avrupa Parlamentosu seçimlerinde oy verme ve aday olma hakk1, 40. maddesinde belediye seçimlerinde aday olma ve oy verme hakk1, 41. maddesinde iyi yönetilme hakk1, 42. maddesinde belgelere erişim hakk1, 43. maddesinde Ombudsman, 44. maddesinde dilekçe hakk1, 45. maddesinde dolaşım ve ikamet özgürlüğü, 46. maddesinde diplomatik koruma düzenlenmiştir. Bu hakların pek çoğu yukarıda zikredilen Avrupa Birliği’nin İşleyişi Hakkındaki Antlaşmada yer almaktadır. $\mathrm{Bu}$ metinde dikkati çeken farklılık "iyi yönetilme hakkı", ile "Birliğin 
kurumlarının belgelerine erişim hakkı"dır. Bu haklar Avrupa Birliği'nin İşleyişi hakkındaki Antlaşma'da sayılan haklara ek olarak Birlik vatandaşlarına sağlanmıştır.

Şartta yer alan bu haklara kimlerin sahip olduğu noktasında bir terim karışıklığı vardır. Bazı haklar (seçme ve seçilme hakları, diplomatik koruma) $\mathrm{AB}$ vatandaşlarına hasredilmişken bazı haklar (belgelere erişim hakkı, Ombudsmana başvurma hakkı, dilekçe hakk1) ise üye devletlerde ikamet eden kişilere tanınmıştır. Hatta herkese tanınan haklar (iyi yönetilme hakkı) dahi mevcuttur. Dolayısıyla Temel Haklar Şartı, diğer antlaşmalardan farklı olarak, bazı hakları Avrupa Birliği'ne üye olmayan devletlerin vatandaşlarına da genişletmektedir.

Avrupa Birliği antlaşmaları çerçevesinde Birlik hukuk düzeninde Birlik vatandaşlığına ilişkin her hakkın vatandaşlara bir üye devleti aşan, Birlik boyutu olan yahut vatandaşı olduğu devletten farklı bir üye devlet ile ilişkili olduğu durumlarda tanındığını, bireyin sadece vatandaşı olduğu devlette yaşadığ1 sorunların yahut sahip olduğu hakların bir iç mesele olması nedeniyle Birlik hukukunu ilgilendirmediğini ve ilgili üye devletin iç hukukuna uygun olarak çözülmesi gerektiğini de hatırlatmak yerinde olacaktır ${ }^{8}$.

\section{Avrupa Adalet Divanı Kararlarında Vatandaşlık}

Avrupa Adalet Divanı Avrupa Topluluklarının kurulmasından bu yana Avrupa bütünleşmesi için önemli kararlar vermiştir. Hatta Adalet Divanı kurucu

Herkes, kendisiyle ilgili işlerin, Birliğin kurum ve kuruluşları tarafından, tarafsız ve adil bir şekilde ve makul bir süre içinde görülmesi hakkına sahiptir.

Bu hak:

- herkesin, kendisini olumsuz biçimde etkileyecek önlemler alınmadan önce, dinlenme hakkını;

- herkesin, gizliliğin meşru yararlarına ve meslek sırlarına saygı göstermek kaydıyla, dosyasına erişme hakkını;

- yönetimin, kararlarının gerekçelerini belirtme zorunluluğunu kapsar.

3.Herkes, üye devletlerin hukuk sistemlerinde ortak olan genel ilkelere uygun bir şekilde, Topluluk kurumları ya da bu kurumlarda görevli memurların görevleri dolayısıyla verdikleri zararın tazmin edilmesi hakkına sahiptir.

4.Herkes, Birliğin kurumlarına, Antlaşmaların resmi dillerinden herhangi biriyle yazabilir ve kendisine aynı dilde cevap verilmelidir.

${ }^{8} \mathrm{Bu}$ hususta Avrupa Adalet Divanının Uecker ve Jacquet birleşik davalar kararı önemlidir. Divan kararında iki Alman vatandaşının Birlik üyesi olmayan ülke vatandaşları olan eşlerinin istihdam piyasasına erişim haklarına ilişkin yaptıkları başvuruda ilgili kişilerin Topluluk içinde Almanya'dan başka bir ülkede çalışmadıkları, ikamet etmedikleri hatta serbest dolaşım bile icra etmediklerini dikkate alarak bu hakkın sadece Alman hükümetine karşı ileri sürülebilecek bir hak olarak görmüş ve konunun Topluluk boyutunun olmadığını karara bağlamıştır. (Uecker ve Jacquet Birleşik Davaları, 1997). 
antlaşmalarda açıkça yer almayan "doğrudan etki doğurma" ya da "AB hukukunun üstünlüğü" gibi prensipleri kendi içtihadı ile oluşturmuş ve bugün AB hukuku olarak adlandırdığımız hukuk düzeninin ortaya çıkmasında büyük bir rol oynamıştır.

Avrupa Adalet Divanı da özellikle kişilerin ve hizmetlerin serbest dolaşımına ilişkin davalarda ortak pazarın ekonomik yönlerinden ziyade sosyal boyutu hatta insani boyutunu ön plana çıkararak çalışanların ev sahibi ülkelere daha çok entegre olmalarını sağlamıştır.

Adalet Divanının AB vatandaşlığı kavramının gelişmesi için yaptığ katkılar vardır. $\mathrm{Bu}$ katkılar yeni bir vatandaşlık teorisi geliştirmek yerine insan hakları alanındaki yetkisini genişleterek ve bu kavramla $A B$ vatandaşlığı kavramını evlendirerek $\mathrm{AB}$ vatandaşlı̆ğnı göçmen bireyler için anlamlı bir kavram haline dönüştürmüştür (Barnard, 2013: 507).

Adalet Divanının AB vatandaşlığı konusunda Maastricht Antlaşması öncesinde de verdiği kararlar mevcuttur. Divan ünlü Bosman ${ }^{9}$ (Bosman Karar1, 1995) kararında vatandaşlık kavramına atıfta bulunmuş ancak bunu sadece dört temel özgürlük hakkındaki kararına dayanak olarak kullanmıştır. Bu durum Divan'ın amacının vatandaşlık kavramını normal bir vatandaşlık olarak değil de pazar vatandaşlığını geliştirmek olarak gördüğü eleştirilerinin yapılmasına neden olmuştur.

Divan 1998 yılında verdiği Martinez Sala kararıyla bu yaklaşımını değiştirmiştir. Martinez Sala Almanya'da ikamet eden bir İspanyol vatandaşı olup Alman devletinin çocuk bakım parasını vermemesi nedeniyle dava açmıştır. Adalet Divanı kararında Birlik vatandaşlığı statüsüne Antlaşmada yer alan haklar ve özgürlükler verildiği, bu haklara Antlaşmanın konu bakımından uygulanması kapsamında vatandaşlık temelinde ayrımcılık yapılmamasının da dâhil olduğunu belirtmiştir (Sala Kararı, 1998).

Adalet Divanı 2001 yılında verdiği Grzelczyk kararında ayrımcılık yasağına ilişkin daha net bir tutum sergilemiştir. Grzelczyk Belçika'da üniversite eğitimi gören bir Fransız vatandaşıdır. Eğitiminin ilk üç yılını kendisi finanse ettikten sonra dördüncü ve son yılı için minimex'e (Belçika minimum gelir garantisi) başvurmuştur. Belçikalı öğrenciler bu yardımdan istifade edebilirken göçmen öğrenciler istifade edememekteydiler. Grzelczyk, Fransız vatandaşı olması

9 Divan "Topluluk Vatandaşlığı” terimini kullanarak Antlaşmanın kişilerin serbest dolaşımı ile ilgili hükümlerinin Topluluk vatandaşlarının Topluluk çapında mesleklerini icra edebilmeleri imkanını sağladığını, bir başka Üye Devlette mesleki faaliyette bulunmak isteyenleri dezavantajlı bir konuma sokabilecek tedbirlerin ise men edildiğini belirtmiştir. 
nedeniyle Antlaşmalara aykırı olarak bu şekildeki bir ayrımcılıktan etkilenmiştir. Adalet Divanı Kararında:

"Birlik vatandaşllğı, açıkça belirtilen istisnalara tabi olmak kaydıyla, Üye Devletlerin vatandaşlarının vatandaşlıkları ne olursa olsun kendilerini yasa önünde eşit muameleden yararlanacakları aynı statüde bulmalarını săglayan asli bir statü olmaya sevk edilmiştir"

demek suretiyle $\mathrm{AB}$ vatandaşlığı kavramının önemini vurgulamıştır (Grzelczyk Kararı, 2001). Barnard'a göre Mahkeme bu kararında Birlik vatandaşlığını serbest dolaşım hakları ile eşit muamele prensibi arasında bir köprü kurmak için kullanmıştır (Barnard, 2013: 511). Buna göre Belçika makamları ev sahibi üye devlet vatandaşları ile diğer üye devlet vatandaşları arasında belli bir ölçüde mali dayanışmanın mevcut olduğundan hareketle kendi vatandaşlarına sağladığı desteğe benzer geçici bir desteği göçmen vatandaşlara da sağlamalıdır (Grzelczyk Kararı, 2001: para.44). Bu karar eşit muamele hakk1 ile birlikte dayanışma ödevinden de bahsetmesi nedeniyle önemli bir karardır ${ }^{10}$.

Adalet Divanı Baumbast kararında Avrupa Birliği’nin İşleyiş̧i hakkındaki Antlaşmanın 21. maddesinde düzenlenen dolaşım serbestisinin doğrudan uygulanabilir, bireysel bir hak olduğunu, bu hak üzerinde konacak her türlü sınırlandırma ve koşulun maddede yer alan bireysel haklar veren hükümlerin ulusal mahkemelerce korunması gerektiğini, konacak sınırlandırma ve koşulların Topluluk hukuku tarafından konan limitlerle ve orantılılık gibi hukukun genel ilkeleri ile uyumlu olması gerektiğini bildirmiştir (Baumbast Kararı, 2002).

Vatandaşlık alanında önemli davalardan birisi de Micheletti davasıdır. Mario Vincente Micheletti Arjantin ve İtalyan vatandaşlıklarına sahip olan ve İtalya'da hiçbir zaman ikamet etmemiş olan bir kişidir. İtalyan vatandaşlığını soy bağı ilkesine göre kazanmıştır ${ }^{11}$. İspanyol makamları İspanyol Medeni Kanununa dayanarak çifte vatandaşlık durumunda, eğer bu vatandaşlıklardan biri İspanyol vatandaşlı̆̆ değilse, kişinin İspanya'ya gelmeden önce mutat meskeninin bulunduğu ülke vatandaşlığının üstün tutulacağını hükme bağlamıştır. Bay Micheletti’nin Arjantin'de aldığı diş hekimliği lisans diploması 1989 yılında İspanya Eğitim ve Bilim Bakanlığı tarafından İspanya

${ }^{10}$ AB Vatandaşlığı ve Dayanışma ilkesine ilişkin daha fazla bilgi için Bkz: (Guild, 2014).

1113 Haziran 1912 tarihli ve 555 sayılı Yasanın 1. Maddesi uyarınca İtalyan bir anneden ya da babadan olan çocuk İtalyan vatandaşıdır. Soy bağı ile vatandaşlık kazanmak için İtalya'da ikamet etme zorunluluğu olmayıp, İtalya dışında ikamet edenler için soy bağına bağlı olarak vatandaşlığın kaçıncı nesle kadar geçeceği hususunda da bir sınırlandırma bulunmamaktadır. (Zincone vd., 2013: 7). 
ve Arjantin arasındaki kültürel işbirliği anlaşması çerçevesinde resmi olarak tanınmıştır. Lisans derecesinin tanınmasından sonra Bay Micheletti bu kez İtalyan pasaportunu kullanarak İspanyol makamlardan geçici yopluluk ikametgah kartı talep etmiş, kendisine altı ay süreli geçici kart verilmiştir. Bu sürenin sonunda bu kez Topluluk vatandaşı olarak daimi ikamet kartı için başvuruda bulunmuş, başvurusu ve takiben yaptığ 1 idari itiraz başvurusu reddedilmiş, bunun üzerine ulusal mahkemede İspanyol makamlarının kararının iptali ve diş hekimi olarak çalışmasını sağlayacak Topluluk vatandaşı ikamet kartı alma hakkının tanınması için dava açmıştır (Micheletti Kararı, 1992).

Adalet Divanı çifte vatandaşlık konusunu değerlendirmiş ve kararında hem bir Üye Devletin hem de üçüncü bir ülkenin vatandaşı olan kişilerin ev sahibi üye devletin yasaları uyarınca üye olmayan devletin vatandaşı olarak kabul edilmeleri nedeniyle özgürlüklerinin kısıtlanmasının Topluluk hukukunun yerleşme özgürlüğüne dair hükümlerince menedildiğini hükme bağlamıştır (Micheletti Kararı, 1992: para.15). Kruma bu kararın 1şı̆̆ında Avrupa Birliği'nin prensip olarak bir üye devlet tarafından uluslararası hukuka uygun olarak verilen vatandaşlığın diğer üye devlet tarafından tanınmasını gerekli kıldığını, kişinin etkin bir bağının olmamasının (örneğin vatandaşı olduğu ülkede hiçbir zaman ikamet etmemiş olması) AB hukuku açısından hiçbir ilgisinin bulunmadığını ifade etmiştir. Dolayısıyla AB'ye üye devletin vatandaşlığına ve üçüncü bir ülke vatandaşlığına birlikte sahip olan bir kişi bir $\mathrm{AB}$ üye devletine geldiğinde, diğer koşulları da yerine getiriyorsa, AB vatandaşlığı temelinde ikamet hakkı talep edebilecektir (Kruma, 2014: 134).

Adalet Divanı kararda bir üye devlet tarafından yapılan vatandaşlığa kabul işleminin başka bir üye devlet tarafından tanınmaması ihtimalini bu kararla ortadan kaldırmasına rağmen üye devletlerin vatandaşlığa kabul ve vatandaşlıktan alıkoymaya ilişkin mutlak takdir yetkilerine sınırlandırmalar getirmiştir. Buna göre her üye devlet uluslararası hukuk çerçevesinde ve Topluluk hukukuna uygun olarak vatandaşlığa kabul ve vatandaşlığın kaybına ilişkin koşulları belirleyebilecektir. Ancak bir üye devletin yasalarının başka bir üye devletin vatandaşlık vermesinin etkilerini sınırlandıracak şekilde o vatandaşlığın tanınmasına ilişkin ilave koşullar getirmesine, Antlaşma ile sağlanan temel özgürlüklerin kullanılması amacıyla, müsaade edilmeyecektir (Micheletti Karar1, 1992: para.10).

Vatandaşlı̆̆ın kaybedilmesine ilişkin Adalet Divanı tarafından verilen kararlardan en önemlisi şüphesiz Rottmann kararıdır. Janko Rottmann Avusturya'nın Graz şehrinde doğmuş Avusturya Cumhuriyeti vatandaşıdır. Hakkında mesleki temelli ciddi dolandırıcılık suçlamasıyla Graz ceza 
mahkemesinde dava açıldıktan sonra 1995 yılında ikametgâhını Almanya'nın Münih şehrine taşımıştır. 1997 yılında Graz ceza mahkemesi Rottmann hakkında yakalama emri çıkarmış, Dr. Rottmann 1998 yılında Alman vatandaşlığı için başvuruda bulunmuştur. Vatandaşlığa alınma işlemleri esnasında hakkında açılan bu davadan bahsetmemiştir. Kişi 1999 yılının Şubat ayında Alman vatandaşlığına kabul edilmiştir. Avusturya yasaları uyarınca kişi hakkında dava devam ederken Alman vatandaşlığına alınması kendisinin Avusturya vatandaşlığını kaybetmesine sebebiyet vermektedir.

Ağustos 1999'da Graz yerel makamları Münih şehrini bu kişi hakkında bilgilendirmiş ve 1995 yılından bu yana davanın sürmekte olduğunu bildirmişlerdir. Bunun üzerinde başvurucunun da savunması alındıktan sonra Bavyera Eyaleti vatandaşlığa alınma kararını geriye dönük etki doğuracak şekilde iptal etmiştir. Bu iptal işlemine karşı dava açılmış Bavyera Eyaleti İdare Mahkemesi 25 Ekim 2005 tarihli kararıyla Bavyera Eyaleti yasalarına göre yapılan vatandaşlığa alınmanın iptali işleminin, ilgili kişi iptal işleminin kesinleşmesiyle vatansız kalacak olsa bile, Alman yasalarına uygun olduğuna karar vermiştir. Dr. Rottmann bu kararı Alman federal idare mahkemesinde temyiz etmiştir. Federal mahkeme başvurular esnasında hile yapılmak suretiyle vatandaşlığın kazanılması durumunda vatandaşlığın geri alınmasının yetkili Alman makamlarının takdirinde olduğunu tespit etmiştir. Yine federal mahkeme başvurucunun mevcut durumda Avusturya yasaları çerçevesinde Avusturya vatandaşlığının hızlıca geri kazanılması koşullarını da sağlamadığını belirlemiştir (Janko Rottmann Kararı, 2010).

Dr. Rottmann Alman vatandaşlığının geriye dönük olarak iptal kararı kesinleştiğinde vatansız olacak, bu işlemin bir başka sonucu olarak da $\mathrm{AB}$ vatandaşlığını kaybedecektir. Bu nedenle Avrupa Adalet Divanına Dr. Rottmann'ın vatandaşlığa alınma kararının Alman makamlarınca iptalinin genel olarak AB hukukuna, özel olarak ise Avrupa Birliği'nin İşleyişi Hakkındaki Antlaşmanın 20. maddesine aykırı olup olmadığı ön karar prosedürü ile sorulmuştur. Adalet Divanı üye devletlerin hileli olarak alınan vatandaşlığı iptal etmeye yetkilerinin olduğunu belirtmiş, ancak vatandaşlıktan çıkarma kararlarının orantılı olması gerektiğini, Antlaşmanın 20. maddesi uyarınca üye devletlerin vatandaşlığa alma işlemini iptal etmek isteyen yetkili makamların $\mathrm{AB}$ vatandaşlarına orijinal vatandaşlıklarını tekrar kazanmalarına müsaade edecek şekilde iptal işlemlerini askıya almaları hususunda zorlanmaları gerektiğine hükmetmiştir (Janko Rottmann Kararı, 2010: para.57-58).

Avrupa Adalet Divanı Rottmann kararında Avrupa Konseyi'nin Avrupa Vatandaşlık Sözleşmesi'ne de atıfta bulunmaktadır. Özellikle Avrupa 
Vatandaşlık Sözleşmesinin 7(1) ve 7(3) maddelerinde belirtildiği üzere vatandaşlığın hile ile yanlış bilgi neticesinde yahut ilgili vakıaların gizlenmesi sonucu kazanılması durumlarında başvurucu vatansız kalacak olsa bile kişinin vatandaşlıktan mahrum edilmesini yasaklamadığı hususuna kararda yer verilmiştir (Janko Rottmann Kararı, 2010: para.52).

Avrupa Adalet Divanı'nın vatandaşlığa ilişkin kararlarında eşit muameleden sonra aile birliğinin korunması hususu da ön plana çıkmaktadır. Vatandaşlık ile ailenin seçtiği ülkede aile birliğinin sağlanması arasında gelişen bir bağdan söz edilebilir. Chen kararında Divan Çin Halk Cumhuriyeti vatandaşları olan anne ve babadan Kuzey İrlanda'da dünyaya gelen (ve bu nedenle doğum yeri esasına göre İrlanda Cumhuriyeti vatandaşlığını kazanan) bebeğin Birlik vatandaşlığı statüsünün sağladığı haklardan istifade edebileceğini hükme bağlamıştır. ${ }^{12}$ Dolayısıyla bebek Avrupa Birliği’nin İşleyişi hakkındaki Antlaşmanın 21.1. maddesi uyarınca Birleşik Krallık’ta ikamet etme hakkına sahip olmaktadır. Buna ilaveten bu haktan yararlanmak için Çin Halk Cumhuriyeti vatandaşı olan annesi de Birleşik Krallık'ta ikamet edebilecektir (Zhu ve Chen Kararı, 2004). Ancak çocuğun ebeveynleri için benzer bir hak $\mathrm{AB}$ vatandaşı çocukların $\mathrm{AB}$ vatandaşı olan ebeveynleri için tanınmamıştır.

Divan Zambrano kararında aile birliğini koruma konusunda bir adım daha öteye gitmiş ve esas hak sahibinin $\mathrm{AB}$ içinde hareket etmediği halde aile birliğinin tercih edilen ülkede sağlanabileceğine karar vermiştir. Ruiz Zambrano Belçika'da iltica başvurusunda bulunmuş bir Kolombiya vatandaşıdır. Başvurusu reddedilen Zambrano'nun sınır dışı edilmesi dolayısıyla Kolombiya'ya dönüşü gündeme gelmiş, kendisi ile birlikte Belçika vatandaş ${ }^{13}$ olan küçük çocuklarının da onunla birlikte Kolombiya'ya dönmesi söz konusu olmuştur. Adalet Divanı kararında Avrupa Birliği’nin İşleyişi

12 Bayan Chen ve kocası Çin Halk Cumhuriyeti tarafından uygulanan "tek çocuk politikası”ndan kaçınmak için Bayan Chen 6 aylık hamile iken Birleşik Krallığa gelmişlerdir. Bayan Chen doğum yaklaştığında Belfast'a gitmiş ve çocuğunu 16 Eylül 2000 tarihinde orada dünyaya getirmiştir. İrlanda Vatandaşlık Yasasının 6(1) bölümü uyarınca İrlanda, İlanda adasında doğan herkesin İrlanda vatandaşı olmasına müsaade ediyordu. Bayan Chen'in amacı toprak esasına göre vatandaşlık veren İrlanda'dan vatandaşlık aldıktan sonra İrlanda vatandaşı kızı ile birlikte İngiltere'de ikamet etmekti. Birleşik Krallık Hükümeti Bayan Chen'in Belfast'a gitmesini AB kukukunun suiistimali olarak kabul edilmesi gereken hileli bir davranış olarak kabul ettiğini bildirmiştir. Fakat Adalet Divanı bu iddiaları çürütmüştür (Kunoy, 2006: 179-190).

${ }^{13}$ Belçika Vatandaşlık Yasasının 10(1) maddesine göre Belçika'da doğan yahut 18 yaşına kadar Belçika vatandaşlığına sahip olmaması durumunda vatansız olacak çocuklar Belçika vatandaşıdırlar (Foblets vd., 2014: 11). 
hakkındaki Antlaşmanın 20. maddesinin üye devletlerin Birlik vatandaşlarının Birlik vatandaşlığ statüsünden kaynaklanan hakların özünden faydalanmalarından mahrum edecek etkiye sahip olan ulusal tedbirleri engellediğini hükme bağlamıştır (Ruiz Zambrano Kararı, 2011).

Divan babanın Belçika'da kalarak çocuklarına bakmasına hükmetmiş, bir üye devletin vatandaşı olan ve orada ikamet eden bakıma muhtaç küçük çocukların üçüncü bir ülke vatandaşı olan babalarına ikamet hakkının ret edilmesi ve aynı kişiye çalışma izninin verilmesinin reddedilmesinin çocukları vatandaş olarak sahip oldukları hakların özünden faydalanmalarından mahrum edecek etkiye sahip olacağını belirtmiştir. Sonuç olarak babaya ailesine destek olabilmesi için çalışma izninin verilmesine karar verilmiştir (Ruiz Zambrano Kararı, 2011: para.44). Zambrano kararında Adalet Divanı'nın AB vatandaşlığına bağlı olan haklardan geçmişte yararlanmaktan daha çok bu haklardan yararlanma potansiyeli üzerinde durduğu ileri sürülmektedir (Hailbronner ve Sanchez, 2011:508).

Bu karar sonrasında Üye Devletlerden Divan'a ağır eleştiriler yöneltilmiştir. Divan da sonraki bazı kararlarında bu karardan geri adım sayılabilecek sinyaller vermiştir $^{14}$. Fakat Dereci davasında Divan aile birliğini temel haklar temelinde ve belki de yetkisini aşacak şekilde korumaya çalışarak şöyle hükmetmiştir:

"Mevcut davada eğer başvuruda bulunan mahkeme esas davadaki uyuşmazlıkların Avrupa Birliği hukuku kapsamında olduğunu değerlendiriyorsa başvurucuların ikamet hakkinın reddedilmesinin Şartın 7. maddesinde sağlanan özel ve aile hayatına sayg gösterme hakkının temellerinin çürütülmesine yol açıp açmadığını incelemelidir. Diğer taraftan bu meselenin Avrupa Birliği hukuku tarafindan kapsanmadĭ̆ı görüşündeyse o takdirde Avrupa İnsan Hakları Sözleşmesinin 8(1). Maddesi ışığında konuyu incelemelidir." ${ }^{\prime 5}$ (Dereci Karar1, 2011).

${ }^{14}$ McCarthy ve Dereci Kararlarında ortada bakıma muhtaç $A B$ vatandaşı bir çocuğun olmadığı ve vatandaşın Birlik topraklarını terk etmeye zorlanmadığı durumlarda geri adım atma sinyali verdiği iddia edilmiştir (Barnard, 2013: 513).

${ }^{15}$ Dereci kararı ailesinde Birlik vatandaşları bulunan Birlik vatandaşı olmayan üçüncü ülke vatandaşlarının ikamet haklarına ilişkin bir karardır. Türkiye açısından önemi ise Murat Dereci'nin Türk vatandaşı olması nedeniyle AET-Türkiye Ortaklık Antlaşması (Ankara Antlaşması) ve 1/80 sayılı Ortaklık Konseyi Kararı ve Katma Protokolün 41. Maddesi çerçevesinde konunun değerlendirilmesidir. 


\section{AB Adalet Divanının Türklere İlişkin Kararları ve "Ortaklık Vatandaşlığı” Kavramı}

Dereci kararı Türkiye-AB ilişkileri kapsamında Türk vatandaşlarının AB ülkelerindeki statüsünün ortaya konması adına çok önemli bir karardır. Bazı yazarlar bu kararın 1şığında Türk vatandaşlarının herhangi bir üçüncü ülke vatandaşından farklı statüye sahip olduklarını belirtmekte ve bu statü için "ortaklık vatandaşlığı" şeklinde yeni bir terim ortaya atmaktadırlar. (Schrauewn ve Vandamme, 2014: 89-110) Türkiye ile Avrupa Birliği arasında ortaklık iliş̧isini kuran Ankara Anlaşması'nın dibacesinde “Türk halkı ile Avrupa Ekonomik Topluluğu içinde bir araya gelmiş halklar arasında gittikçe daha sık1 bağlar kurmaya azimli olarak" bu anlaşmanın imzalandığı belirtilmiştir. Anlaşmada serbest dolaşıma ilişkin hükümler de bulunmakta olup bu konularda Avrupa Birliği’nin İşleyişi Hakkındaki Antlaşmanın serbest dolaşıma ilişkin maddelerinin taraflara rehberlik edeceği ifade edilmiştir. Ancak söz konusu maddeler doğrudan etki doğurmadığı için Türk vatandaşları bu maddelere dayanarak serbest dolaşımdan istifade edememektedir.

Türkiye ile Avrupa Birliği arasında kurulan ilişkinin özel bir ilişki olduğu söylenebilir. AB ile ekonomik bütünleşme açısından Türkiye'yi geçebilen sadece Avrupa Ekonomik Alanı'nın AB üyesi olmayan ülkeleridir (Norveç, Liechtenstein ve İzlanda). Bu durum malların serbest dolaşımı için geçerli olmayabilir, çünkü Türkiye ile $\mathrm{AB}$ arasında kurulan gümrük birliği bu ülkeler ile $\mathrm{AB}$ arasında mevcut değildir ${ }^{16}$. Bu kapsamda malların serbest dolaşımı ile kişilerin serbest dolaşımı arasındaki bağları da görmezden gelmemek gerekmektedir (Tezcan/Idriz, 2009: 1631).

Yine Türkiye ile AB arasındaki ilişki Ortaklık ve İşbirliği Anlaşmaları ile AB-Akdeniz Anlaşmalarından da farklıdır. AB-Türkiye ortaklı̆̆ının siyasi amacı işçilerin serbest dolaşımı, hizmetlerin serbestçe sağlanması ve yerleşme özgürlüğü iken Barselona süreci kapsamında Kuzey Afrika ve Orta Doğu ülkeleri ile imzalanan işbirliği anlaşmalarının hedefi bu ülkelerden gelen göç baskısını azaltmak için yerel düzeyde yaşam koşullarının iyileştirilmesinden ibarettir (Schrauewn ve Vandamme, 2014: 96).

Ankara Anlaşması, AB ülkelerinde ikamet eden Türk vatandaşlarına AB'de çalışan üçüncü ülke vatandaşlarından ziyade bir başka üye devlette çalışan $A B$ üyesi ülke vatandaşlarının statüsüne yakın bir statü sağlamaktadır.

16 Türkiye dışında $\mathrm{AB}$ ile gümrük birliği kuran ülkeler Andorra, San Marino ve Monaco ülkeleridir. 
AB Adalet Divanı her üye devletin Türk vatandaşlarının ülkelerine ilk girişlerine ilişkin düzenlemelerinin münhasır yetkisini her zaman kabul etmesine rağmen özellikle Savaş kararı ile bu imtiyazın da sınırlı bir şekilde yorumlanması gerektiğini ortaya koymuştur. Abdülnasır Savaş ve ailesi bir ay geçerli bir turist vizesi ile İngiltere'ye giriş yapmış ve sonrasında 11 yı1 boyunca İngiltere'de kalmış ve burada iş kurmuştur. Adalet Divanı Savaş ailesinin 11 yıl boyunca ülkede yasalara aykırı bir şekilde bulunmuş olmalarına rağmen Katma Protokol'ün 41.1. maddesinde yer alan stand-still ${ }^{17}$ şartından yararlanabileceğine hükmetmiştir (Savaş Kararı, 2000).

Abdülnasır Savaş'ın İngiltere'ye ilk girişi turist vizesi ile ve yasalara uygun bir şekildedir. Turist vizesinin sona ermesinden sonra İngiltere'de kalmaya devam ettikleri halde Adalet Divanı stand-still şartından istifade edeceklerini belirtmiştir. Tüm ve Darl davasında ise Veli Tüm ve Mehmet Darı'nın İngiltere'ye ilk girişlerinde dahi sorun vardır. Bu kişiler İngiltere'ye gemi ile gelmişler ve sığınma başvurusunda bulunmuşlardır. Tüm ve Darı'nın sığınma başvuruları reddedilmiş ve kendilerine 1971 tarihli Göç Yasasının 11(1) bölümü hükümleri uyarınca geçici kabul sağlanmıştır. Veli Tüm ve Mehmet Darı kendi adlarına iş kuracakları gerekçesiyle vize başvurusunda bulunmuşlardır. Vize başvuruları reddedildikten sonra konu yargıya intikal etmiştir. İngiliz hükümeti Tüm ve Darı'nın İngiltere'ye yasalara uygun bir şekilde gelmediklerini bu nedenle stand-still prensibinden yararlanamayacaklarını ileri sürmüştür. Adalet Divanı verdiği kararda kendi işlerini kurmayı amaçlayan Türk vatandaşlarının üye devlete ilk kez girişlerine ilişkin maddi ya da prosedürel koşulların da stand-still prensibi çerçevesinde değerlendirilmesi gerektiğini ve bu nedenle ülkeye ilk girişe ilişkin kuralların da bu prensip çerçevesinde ele alınıp yeni kısıtlamalar getirilmesinin yasaklanmış olduğuna dikkati çekmiştir (Tüm ve Darı Kararı, 2007).

Adalet Divanı'nın Türk vatandaşlarının serbest dolaşımına ilişkin kararlarında Ankara Anlaşması'nın ruhuna uygun olarak AB ile Türkiye arasındaki ortaklığın daha ileri aşamalara götürülmesini hedefleyen entegrasyonu destekler nitelikte yorumlar yaptığını ve ortaklık rejimi çerçevesinde Türklerin $\mathrm{AB}$ içindeki statülerini $\mathrm{AB}$ vatandaşlarının statüsüne yaklaştıran bir tutum sergilediğini söylemek yanlış olmayacaktır.

${ }^{17}$ Avrupa Birliği Genel Sekreterliği tarafından hazırlanan AB Terimler Sözlüğünde standstill şartının Türkçe karşılığı olarak "mevcudun dondurulması kuralı" ya da "dondurma kaydı" verilmiştir. 23 Kasım 1970 tarihinde kabul edilen Avrupa Ekonomik Topluluğu ile Türkiye Arasında Ortaklık İlişkisi Kurulmasına Dair Anlaşmaya Katma Protokol'ün 41.1. maddesiyle taraflar, aralarında, yerleşme hakkı ve hizmetlerin serbest edimine yeni kısıtlamalar koymaktan sakınacaklarını taahhüt etmişlerdir. 


\section{Sonuç}

$\mathrm{AB}$ vatandaşlı̆̆ kavramı hayata geçirildiği Maastricht Antlaşması'ndan bu yana hemen hemen tüm önemli antlaşmalarda yer bulan, gelişmekte olan ve kapsamı genişleyen bir kavram olmuştur. Özellikle iki binli yıllardaki Adalet Divanı kararları bu gelişime önemli katkılarda bulunmuştur. Yukarıda incelenen mahkeme kararları 1şığında Avrupa Birliği’nin vatandaşlığa ilişkin kabul ettiği ilkeleri şöyle sıralayabiliriz:

1. $\mathrm{AB}$ vatandaşlığı ikincil bir statüdür ve üye devlet vatandaşlığına bağlıdır. Herhangi bir üye devletin vatandaşı olmayanlar $A B$ vatandaşlığı statüsünü kazanamazlar. Ancak üye devlet vatandaşlığı sadece vatandaşı olunan devlet nezdinde haklar bahşederken, $\mathrm{AB}$ vatandaşlığı üye devlet vatandaşlarına tüm üye devletlerde sahip olacakları ve bu devletlere karşı ileri sürebilecekleri bir dizi haklar bahşetmektedir.

2. $A B$ vatandaşlı̆̆ının kazanılması ya da kaybedilmesi durumlarında $A B$ üye devletlerin vatandaşlık konusunda sahip oldukları takdir yetkisini kısıtlayabilmektedir. Özellikle Micheletti kararında ve takip eden kararlarda Adalet Divanı bir üye devletin vatandaşı olarak kabul ettiği bir kişinin üçüncü bir ülke ile daha etkin bağları olduğu gerekçesiyle kişiyi üçüncü ülke vatandaşı kabul edip $\mathrm{AB}$ vatandaşlarının sahip oldukları haklardan mahrum bırakmanın $\mathrm{AB}$ hukukuna aykırı olduğunu hükme bağlamıştır. Dolayısıyla devletlerin $\mathrm{AB}$ vatandaşlığ1 statüsünü etkileyecek böyle kararlar almasının önüne geçilmiştir. Divan Micheletti kararında üye devletlerin vatandaşlığa alma ve vatandaşlığın kaybı şartlarını belirlemede sahip olduğu münhasır takdir yetkisinin sınırları olduğunu ve bu yetkinin “AB hukukuna uygun olarak" kullanılması gerektiğini belirtmiştir.

3. AB vatandaşlığ 1 , bireylere genellikle haklar bahşeden bir statüdür. $\mathrm{Bu}$ durum $\mathrm{AB}$ vatandaşlığını hem haklar hem de ödevler yükleyen klasik devlet vatandaşlığından ayıran unsurlardan birisidir. Ancak $A B$ vatandaşlarına bazı ödevlerin de yüklenmesi mümkündür ${ }^{18}$. Bugüne kadar $\mathrm{AB}$ vatandaşlarının

${ }^{18} \mathrm{Bu}$ noktada Avrupa Birliği Temel Haklar Şartı'nda Bölüm IV olarak yer verilen "Dayanışma" başlığından bahsetmek gerekir. Bu başlık altında yer alan 34. Maddede "Avrupa Birliği sınırları içinde, yasal olarak ikamet eden ve dolaşan herkes, Topluluk hukuku ile ulusal hukuk ve uygulamalara uygun olarak, sosyal güvenlik ve diğer sosyal yardımlardan yararlanma hakkına sahiptir." şeklinde bir düzenleme yer almaktadır. Yukarıda atıfta bulunulan Grzelczyk kararı da dikkate alındığında Birlik vatandaşlarının kendi devletleri dışında bir başka Üye Devlette sosyal yardımlardan istifade etmeleri o devlette yaşayan bireylerin vergileri ile finanse edilen yardımlardan pay almaları Birlik vatandaşlarına yüklenen bir "dayanışma” ödevi gibi görülebilir. 
yerine getirmesi gereken ödevlere ilişkin bir düzenleme bulunmaması ileride bu yönde gelişmelerin olmayacağı anlamına gelmez.

$\mathrm{AB}$ vatandaşlığı kavramının yanı sıra ortaya atılan bir diğer kavram da ortaklık vatandaşlığ 1 kavramıdır. AB üyesi devletlerde Türk vatandaşlarının statüsüne ilişkin olarak ortaya atılan bu kavramın arkasında da $\mathrm{AB}$ Adalet Divanı tarafından oluşturulan önemli bir içtihat mevcuttur. Günümüzde $A B$ üyesi devletlerde yaşayan üçüncü ülke vatandaşlarının da bazı haklara sahip olması konusu gündemde olup $\mathrm{AB}$ vatandaşlığı içinde değerlendirilen bazı hak kategorilerinden $\mathrm{AB}$ üyesi devletlerin vatandaşı olmayan üçüncü ülke vatandaşlarının da yararlanmaları söz konusu olabilecektir. 


\section{Kaynakça:}

ABRG No L 166, 20. (1987). 87/327/EEC sayll Üniversite Öğrencilerinin Hareketliliği hakkında Avrupa Topluluğu Eylem Planı (ERASMUS).

ABRG No L 180, 28. (1990). 90/365/EEC sayll Mesleki Faaliyetleri Sona Eren İş̧̧ilerin ya da Serbest Meslek Sahiplerinin İkamet Haklarına İlişkin Yönerge.

ABRG No L 180,26. (1990). 90/364/EEC sayılı İkamet Hakkına İlişkin Yönerge.

ABRG No L 180,30. (1990). 90/366 EEC sayılı Öğrencilerin İkamet Haklarına İlişkin Yönerge.

Amsterdam Antlaşması. (2000). Bütünleşmiş Haliyle Avrupa Birliği Kurucu Antlaşmaları Resmi Olmayan Türkçe Çevirisi, 162. (C. Bolayır, Çev.) İstanbul: İktisadi Kalkınma Vakfı. <http://www.ikv.org.tr/images/files/A6tr.pdf>, (15 Şubat 2017).

Avrupa Birliği Temel Haklar Şartı (2011). Avrupa Birliği Temel Haklar Şartı Resmi Olmayan Türkçe Çevirisi. Avrupa Birliği ile İlişkiler Genel Müdürlüğü.

$<$ http://www.eskisehirab.gov.tr/userfiles/files/AVRUPA\%20B\%C4\%B0RL $\% \mathrm{C} 4 \% \mathrm{~B} 0 \% \mathrm{C} 4 \% 9 \mathrm{E} \% \mathrm{C} 4 \% \mathrm{~B} 0 \% 20 \mathrm{TEMEL} \% 20 \mathrm{HAKLAR} \% 20 \% \mathrm{C} 5 \% 9 \mathrm{EAR}$ TI.pdf $>$, (17 Şubat 2017).

Avrupa Birliği'ni Kuran Taslak Antlaşma, Bulletin of the European Communities. (1984, Şubat) <http://www.cvce.eu/obj/draft_treaty_ establishing_the_european_union_14_february_1984-en-0c1f92e8-db444408-b569-c464cc1e73c9.html>, (15 Şubat 2017).

Avrupa Konseyi Avrupa Vatandaşlık Sözleşmesi. (2008) Avrupa Vatandaşlık Sözleşmesi Resmi Olmayan Türkçe Tercümesi, (A. Aykaç, Çev.), TBB Dergisi, 77:359-374.

Barnard, C. (2013) "Citizenship of the Union and the Area of Justice: (Almost) The Court's Moment of Glory", Court of Justice of the European Union (der.) The Court of Justice and Construction of Europe: Analysis and Perspectives on Sixty Years of Case-law, (Lahey: T.M.C. Asser Press): 505522.

Baumbast Karar1, Baumbast and $R v$ Secretary of State for the Home Department, C-413/99 (Avrupa Adalet Divanı Eylül 17, 2002). $<$ http://curia.europa.eu/juris/showPdf.jsf?text=\&docid=47668\&pageIndex $=$ 
$0 \&$ doclang $=E N \&$ mode $=1$ st $\&$ dir $=\&$ occ $=$ first $\&$ part $=1 \& \operatorname{cid}=275980>$, Mart 2017).

Bosman Karar1, Union Royale Belge des Sociétés de Football Association ASBL v Jean-Marc Bosman , C-415/93 (Avrupa Adalet Divanı Aralık 15, 1995). $<$ http://curia.europa.eu/juris/showPdf.jsf?text=\&docid=99445\&pageIndex= $0 \&$ doclang $=$ EN\&mode $=1$ st\&dir $=\&$ occ $=$ first $\&$ part $=1 \& \operatorname{cid}=83728>,(18$ Mart 2017).

Bosniak, L. (2002) "Constitutional Citizenship Through the Prism of Alienage", Ohio State Law Journal, 63:1285-1326.

Closa, C. (1992) "The Concept of Citizenship in the Treaty on European Union", Common Market Law Review, 29: 1137-1169.

Closa, C. (1995) "Citizenship of the Union and Nationality of Member States", Common Market Law Review, 32: 487-518.

Condinanzi, M., Lang, A., ve Nascimbene, B. (2008) Citizenship of the Union and Free Movement of Persons, (Leiden: Martinus Nijhoff Publishers).

Dereci Karar1, Murat Dereci and Others v. Bundesministerium für Inneres, C256/11 (Avrupa Adalet Divan1 Kasim 15, 2011). $<\mathrm{http}$ ://curia.europa.eu/juris/document/document.jsf?text=\&docid $=114222 \&$ pageIndex $=0 \&$ doclang $=\mathrm{EN} \& \operatorname{mode}=1$ st $\&$ dir $=\&$ occ $=$ first $\&$ part $=1 \& \operatorname{cid}=9652$ 4>, (18 Mart 2017)

Edinburgh AB Zirvesi, Bölüm B-Danimarka ve Avrupa Birliği Antlaşması. (1992, Aralı 12). AB Zirvesi içinde toplanan Devlet ve Hükümet Başkanları'nın Danimarka tarafindan ileri sürülen Avrupa Birliği Antlaşması hakkımdaki bazı problemlere ilişkin kararı EK-1. Edinburgh. $<$ http://www.europarl.europa.eu/summits/edinburgh/b1_en.pdf>, (10 Şubat 2017).

Foblets, M., Yanasmayan, Z., ve Wautelet, P. (2014) Country Report: Belgium, RSCAS/EUDO-CIT-CR 2013/27, (Badia Fiesolana: European University Institute Publication).

Grzelczyk Kararı, Rudy Grzelczyk v Centre public d'aide sociale d'OttigniesLouvain-la-Neuve, C-184/99 (Avrupa Adalet Divanı Eylül 20, 2001). $<$ http://curia.europa.eu/juris/showPdf.jsf?text=\&docid=46599\&pageIndex $=$ $0 \&$ doclang $=\mathrm{EN} \&$ mode $=1$ st\&dir $=\&$ occ $=$ first \&part $=1 \& \mathrm{cid}=216957>,(3 \mathrm{Mart}$ 2017). 
Guild, E. (2014) "Does European Citizenship Blur the Borders of Solidarity?", E. Guild, C. J Gortazar Rotaeche, D. Kostakopulou (der.) The Reconceptualization of European Union Citizenship, (Leiden: Brill Nijhoff): 189-208.

Hailbronner, K. (2006) "Nationality in Public International Law and European Law", in Bauböck, R. (der.), Acquisition and Loss of Nationality: Policies and Trends in 15 European states, I (Amsterdam: Amsterdam University Press): $35-104$.

Hailbronner, M. ve Iglesias Sanchez, S. (2011) "The European Court of Justice and Citizenship of the European Union: New Developments towards a Truly Fundamental Status", Vienna Online journal on International constitutional law, 5, Say1: 4: 498-537.

Janko Rottmann Karar1, Janko Rottman v. Freistaat Bayern, C-135/08 (Avrupa Adalet Divan1 March 2, 2010), <http://curia.europa.eu/juris/document/ document.jsf?text $=\&$ docid $=75336 \&$ pageIndex $=0 \&$ doclang $=$ EN\&mode $=1$ st $\& \operatorname{dir}=\&$ occ $=$ first\&part=1\&cid=97872>, (15 Mart 2017).

Kadelbach, S. (2003) Union Citizenship, Jean Monnet Working Paper 9/03, (Heidelberg: Max Planck Institute for Comparative Public Law and International Law).

Kingdom of the Netherlands (2015) One Kingdom - Four Countries; European and Caribbean, <https://www.government.nl/documents/leaflets/2015/06/05/ kingdom-of-the-netherlands-one-kingdom-four-countries-european-andcaribbean>, (12 Mart 2017).

Kochenov, D. (2009) European Citizenship and the Difficult Relationship Between Status and Rights, Columbia Journal of European Law, 15: 169237.

Kruma, K. (2014) EU Citizenship, Nationality and Migrant Status an Ongoing Challenge, (Leiden: Martinus Nijhoff Publishers).

Kunoy, B. (2006) A Union of National Citizens: The Origins of the Court's Lack of Avant-Gardisme in the Chen Case, Common Market Law Review,43: 179-190.

Maastricht Antlaşması (1992) Avrupa Birliğini Kuran Andlaşma (Maastricht Andlaşması) Resmi Olmayan Türkçe Çevirisi(118). (C. Baydarol, Çev.) (İstanbul: İktisadi Kalkınma Vakfı Yayınları), <http://www.bumko.gov.tr/ Eklenti/2838,maastrichttrpdf.pdf?0>, (20 Şubat 2017). 
Micheletti Karar1, Mario Vicente Micheletti and others $v$ Delegación del Gobierno en Cantabria, C-369/90 (Avrupa Adalet Divanı Temmuz 7, 1992), <http://curia.europa.eu/juris/showPdf.jsf?text=\&docid=97581\& pageIndex $=0 \&$ doclang $=\mathrm{EN} \&$ mode $=1$ st $\&$ dir $=\&$ occ $=$ first $\&$ part $=1 \& \operatorname{cid}=1892$ 56>, (16 Mart 2017).

Lizbon Antlaşması (2011) Avrupa Birliği Antlaşması ve Avrupa Birliğgi'nin İşleyiş Hakkında Antlaşma. (Lizbon Antlaşması) Resmi Olmayan Türkçe Çevirisi, (Ankara: Avrupa Birliği Genel Sekreterliği), $<$ http://www.ab.gov.tr/files/pub/antlasmalar.pdf>, (20 Şubat 2017).

Nice Antlaşması (2003) Avrupa Topluluklarını Kuran Antlaşmalar ve İlgili Bazı Kararları Değiştiren Antlaşma (Nice Antlaşması) Resmi Olmayan Türkçe Çevirisi, 174. (S. G. Çapanoğlu, ve E. Uyanusta, Çev.) (İstanbul: İktisadi Kalkınma Vakfi), <http://www.bumko.gov.tr/Eklenti/2846, nicetrpdf.pdf?0>, (20 Şubat 2017).

Pennings, F. (2013) Non-Discrimination on the Ground of Nationality in Social Security: What are the Consequences of the Accession of the EU to the ECHR?, Utrecht Law Review, 9:118-134.

Ruiz Zambrano Kararı, Gerardo Ruiz Zambrano v. Office national de l'emploi (ONEm), C-39/09 (Avrupa Adalet Divanı Mart 11, 2011) $<$ http://curia.europa.eu/juris/document/document.jsf?text=\&docid=80236\&p ageIndex $=0 \&$ doclang $=$ EN\& mode $=1$ st $\&$ dir $=\&$ occ $=$ first $\&$ part $=1 \&$ cid $=50352$ $>$, (15 Mart 2017).

Sala Karar1, María Martínez Sala v. Freistaat Bayern, C-85/96 (Avrupa Adalet Divan1 May1s 12, 1998), <http://curia.europa.eu/juris/showPdf.jsf?text= $\&$ docid $=43841 \&$ pageIndex $=0 \&$ doclang $=E N \&$ mode $=1$ st $\&$ dir $=\& o c c=$ first $\& p$ art=1\&cid=216333>, (18 Mart 2017).

Savaş Kararı, The Queen v Secretary of State for the Home Department, ex parte Abdulnasir Savas, C-37/98 (Avrupa Adalet Divanı May1s 11, 2000), $<$ http://curia.europa.eu/juris/showPdf.jsf?text $=\&$ docid=45263\&pageIndex $=$ $0 \&$ doclang $=\mathrm{EN} \&$ mode $=1$ st $\&$ dir $=\&$ occ $=$ first $\&$ part $=1 \& \mathrm{cid}=88490>,(17$ Mart 2017).

Schrauewn, A., Vandamme, T. (2014) "Towards a Citizenship of the Association? On the Future Non-discrimination, Preferential Treatment and Standstill Clauses in the EU-Turkey Association Regime", E. Guild, C. J. Gortazar Rotaeche, \& D. Kostakopoulou (der.) The Reconceptualization of European Union Citizenship, (Leiden: Brill Nijhoff), ss. 89-110. 
TC. Avrupa Birliği Genel Sekreterliği (2009) Avrupa Birliği Terimler Sözlüğü, (Ankara: Matus Basımevi).

Tezcan/Idriz, N. (2009) "Free Movement of Persons Between Turkey and the EU: To Move or not to Move? The Response of the Judiciary", Common Market Law Review, 46: 1621-1665.

Tindermans, L. (1976) "Tindermans Raporu”, O. Kozluca (çev.), (İstanbul: İktisadi Kalkınma Vakfi).

Tüm ve Darı Kararı, Veli Tüm and Mehmet Darl v Secretary of State for the Home Department, C-16/05 (Avrupa Adalet Divanı Eylül 20, 2007). $<$ http://curia.europa.eu/juris/showPdf.jsf?text=\&docid=62973\&pageIndex $=$ $0 \&$ doclang $=E N \&$ mode $=1$ st $\& \operatorname{dir}=\&$ occ $=$ first $\&$ part $=1 \& \operatorname{cid}=185012>$, Mart 2017).

Uecker ve Jacquet Birleşik Davaları, Land Nordrhein-Westfalen v Kari Uecker and Vera Jacquet $v$ Land Nordrhein-Westfalen, C-64/96 ve C-65/96 (Avrupa Adalet Divanı Haziran 5, 1997), <http://curia.europa.eu/juris/ showPdf.jsf?text $=\&$ docid $=100859 \&$ pageIndex $=0 \&$ doclang $=$ en $\&$ mode $=1$ st $\&$ $\operatorname{dir}=\&$ occ $=$ first\&part=1\&cid=38669>, (14 Mart 2017).

Uluslararası Daimi Adalet Divanı, Tunus ve Fas Vatandaşlık Kararnameleri Meselesi Tavsiye Görüşü, 7 Şubat 1923, s.24, <http://www.icjcij.org/files/permanent-court-of-international-justice/serie_B/B_04/Decrets de_nationalite_promulgues_en_Tunisie_et_au_Maroc_Avis_consultatif 1.pdf >, (18 Şubat 2017).

Zhu ve Chen Karar1, Kunqian Catherine Zhu and Man Lavette Chen $v$ Secretary of State for the Home Department, C-200/02 (Avrupa Adalet Divan1 Ekim 19, 2004), <http://curia.europa.eu/juris/showPdf.jsf?text= $\&$ docid $=49231$ \&pageIndex $=0 \&$ doclang $=E N \&$ mode $=1$ st $\&$ dir $=\& o c c=$ first $\& p$ art $=1 \&$ cid=41696>, (16 Mart 2017).

Zincone, G., Basili, M. (2013) Report on Italy, Country Report, RSCAS/EUDO-CIT-CR 2013/3, (Badia Fiesolana: European University Institute Publication). 